\title{
Ultrastructure of the Myelinated and Unmyelinated Nerve Fibers of the Tongue Mucosa of Albinus Rat (Wistar) with Aging
}

\author{
Ultraestructura de las Fibras Nerviosas Mielínicas y Amielínicas de la \\ Mucosa Lingual de ratas Albinas (Wistar) Envejecidas
}

"Grisolia, D. F.; "* Ogawa, K.; "Motoyama, A.A.; "Kronka, M. C.; "Carneiro Jr., J. T.; "Duro, C. C. \& *Watanabe, I.

GRISOLIA, D. F.; OGAWA, K.; MOTOYAMA, A. A.; KRONKA, M. C.; CARNEIRO JR., J. T.; DURO, C. C. \& WATANABE, I. Ultrastructure of the myelinated and unmyelinated nerve fibers of the tongue mucosa of Albinus rat (Wistar) with aging. Int. J. Morphol., 24(3):407-412, 2006.

SUMMARY: The purpose of this paper was to study the sensory myelinated and unmyelinated nerve fibers found in the subepithelial lamina propria of tongue mucosa of aging rats. It was used the silver impregnation, transmission electron microscopy methods and morphometric measurements. The results revealed that subepithelial nerve fiber bundles of the anterior, medium and posterior regions of tongue were arise from deep muscular layer of tongue. The nerve fiber bundles were verified inside of the connective tissue of lamina propria. These nerve fibers branched several times and into the connective tissue papillae they form a single or ramified sensory nerve endings. The fungiform and vallate papillae contain numerous nerve terminals. The fine structure demonstrated that in the axoplasm were noted the presence of neurofilaments, mitochondria and microtubules. Although the morphometric data of myelinated fibers showed that about $44 \%$ having larger diameter between 3 to $4 \mu \mathrm{m}$ and the mean value was $4.5 \mu \mathrm{m}$. The largest diameter was $12 \mu \mathrm{m}$ and the smaller was $1.4 \mathrm{um}$. The smallest diameter ranges from 1 to $3 \mu \mathrm{m}$, being that the mean value was $2.33 \mu \mathrm{m}$. Concerning to the thickness of myelin sheets were revealed the values ranging from 0.2 to $0.8 \mu \mathrm{m}$ being that the $90 \%$ present the values around $0.5 \mu \mathrm{m}$. The unmyelinated fibers showed the largest diameter (62\%) varying from 0.25 to $0.75 \mu \mathrm{m}$. The mean value was $0.6 \mu \mathrm{m}$ being the maximum value was $3.17 \mu \mathrm{m}$ and the minimum was $0.2 \mu \mathrm{m}$. The smallest diameter was obtained in $44 \%$ of unmyelinated fibers which the diameter ranges from 0.2 to $0.4 \mu \mathrm{m}$. Then maximum value obtained was $1 \mu \mathrm{m}$ and the minimum was $0.12 \mu \mathrm{m}$.

KEY WORDS: Nerve fiber; Myelinated fiber; Unmyelinated fiber; Tongue mucosa; Aging rat; TEM.

\section{INTRODUCTION}

According to the Sato \& Sato (1992) the tongue of mammals is constituted by stomatognatic structures revealing the specialized organ related to general sensory and taste buds. Kubota et al. (1966) observed the filiform papillae of dorsal part of porcupine tongue mentioning the presence of few nerve fibers. They noted thepresence of well developed folliate papillae including the taste buds, being that there are concentrated plexoform nerve fibers in the lateral part of papillae. Eto (1959) reported that the filiform papillae of cats present numerous sensory nerve fibers with single terminal endings. Kubota et al. (1963) showed that in the dorsal part of tongue (cangurus) there are fungiform papillae containing few taste buds.

The fungiform papillae in mammals may identified nerve fibers which act in the transmission of stimulus of tact, temperatura, nociceptive and taste buds. Fonoff et al. (1987, 1989) studied the sensory nerve endings of Cebus apella tongue utilizing the silver impregnation method and found the subepitelial single and complex sensory nerve endings. The authors verified that fungiform papilla contains numerous ramified nerve fibers forming a subepithelial plexus.

Then aim of this paper is to elucidate the present of myelinated and unmyelinated nerve fibers in the lamina propria of tongue mucosa of aging rats employing the light and transmission electron microscopy methods.

\section{MATERIAL AND METHOD}

Three aging rats with two years old were anaestized with intraperitoneal injection of pentobarbital sódic (Hypnol $3 \%$ ) and the tongue structures were removed carefully.

\footnotetext{
* Department of Anatomy, Institute of Biomedical Sciences, University of São Paulo, Brasil. dfgrisolia@uol.com.br

* Department of Anatomy, University of Fukuoka School of Medicine, Japan.

This paper was supported in part by CNPq Grant.
} 
For light microscopy, were used 3 animals. The tongue were removed and divided in three portions: anterior, medium and posterior, which were fixed in $10 \%$ formolin solution, during 20 days, at room temperature. Then, the tissues were cooled in liquid nitrogen and the sections of 40 to $50 \mu \mathrm{m}$ were obtained in Kriostat Young. The tissues were treated for silver impregnation method, according to the technique reported by Winkelmann \& Schmitt (1957) and Watanabe \& Semprini (1985). The samples were mounted and examined by Zeiss photomicroscopy.

For transmission electron microscopy, the small pieces of anterior, medium and posterior parts of tongue were fixed in modified Karnovsky solution, containing 2.5\% glutaradehyde, $2 \%$ paraformaldehyde in $0.1 \mathrm{M}$ sodium phosphate buffer at $4{ }^{\circ} \mathrm{C}(\mathrm{pH} 7.3)$, according to the technique reported by Watanabe \& Yamada (1983). Then, the tissues were rinsed in phosphate buffer for $15 \mathrm{~min}$, and postfixed in $1 \%$ buffered osmium tetroxide for $2 \mathrm{~h}$ at $4{ }^{\circ} \mathrm{C}$. The dehydration was done at room temperature with increasing series of ethanol, and they were embedded in Spurr resin. Thick sections, about $0.5 \mu \mathrm{m}$ were cut on a Sorvall Porter Blum type MT-2B ultra microtome and stained in toluidin blue solution for histological observations. The thin sections were made and colected in 200 mesh, counterstained with uranyl acetate (Watson, 1958) and lead citrate (Reynolds, 1963) and examined in a JEOL-1010, transmission electron microscope at $80 \mathrm{kV}$.

In the morphometry study, the subepitelial myelinated and unmylinated fibers were measured and analysed.

\section{RESULTS}

Light microscopy. The oral mucosa of aging rat tongue revealed the presence of a superficial layer lined by stratified epithelium and the lamina propria. The nerve fibers present a irregular traject constituting a bundles (Fig. 1) or single fibers (Fig. 2). They arise from deep portion of muscle layer of tongue revealing a thick bundles and shows into the subepithelial connective tissue of papillae (Fig. 2). The subpapillar or intrapapillar nerve fibers plexus are noted clearly in silver stanning methods. Some sensory terminal fibers are formed into the conncetive tissue papillae.

In aging rat tongue mucosa, usually the filiform papillae present the single sensory nerve endings (Fig. 1) differering those found in the fungiform and vallate papillae. The thin nerve fibers run closely to the basement membrane of epithelial cells (Fig. 2). In the fungiform papillae were noted numerous thin sensory nerve terminals which subdivided several times. The thin nerve fibers penetrate into the epithelial layer constituting the intraepithelial terminal axons. In the vallate papilla were observed numerous myelinated sensory nerve fibers into the connective tissue. These nerve fibers branched several times and formed ramified or single terminal axons. The intra-epithelial axons were found closely to the taste buds.

Transmission electron microscopy. The fine structure of myelinated nerve fibers (Fig. 3) were surrounded by collagen fibers of endoneurium and clearly examined by transmission electron microscopy. The lamina propria of tongue mucosa of aging rats, revealed the thin myelinated (Fig. 4) and unmyelinated nerve fibers (Fig. 5) are enveloped by perineural cell cytoplasmic laminae. Each axon has a thin lamina of Schwann cell sheets enveloping both myelinated and unmyelinated nerve fibers (Figs. 4 and 5). The basement membrane of perineural cell was noted (Fig. 4).

The myelin sheet of myelinated nerve fiber was varied in thickness and diameter. At periphery of the myelin sheet is noted the Schawnn cell lamina and the fine collagen fibers (Fig. 6). The bundles of unmyelinated collagen fibers were examined containing several number of fine fibers surrounded by thin sheet of Schwann cell (Figs. 7 and 8). The grouping of unmyelinated fibers are enveloped by Schwann cell lamina and at periphery, may observe the bundles of collagen fibers (Fig. 9). Both axons of nerve fibers present neurofilaments, microtubules and mitochondria (Figs. 5 and 7). The endoneurium is characterized by the presence of transversal and longitudinal dispositions of collagen fibers (Fig. 10). The cytoplasm of perineural cells revealed the mitochondria, base-ment membrane and some bundles of collagen fibers (Fig. 11).

Although the morphometric data of myelinated fibers showed about $44 \%$ of those fibers having larger diameter between 3 to $4 \mu \mathrm{m}$ as showed in Fig. 12 and the mean value was $4.5 \mu \mathrm{m}$. The largest diameter was $12 \mu \mathrm{m}$ and the minimum was $1.4 \mu \mathrm{m}$. The smallest diameter ranges from 1 to $3 \mu \mathrm{m}$, being that the mean value was $2.33 \mu \mathrm{m}$ as noted in Fig. 13.

Concerning to the thickness of myelin sheets threre were $90 \%$ of the values ranging from 0.2 to $0.8 \mu \mathrm{m}$ being that the $33 \%$ present the values between 0.5 to $0.6 \mu \mathrm{m}$ (Fig. 14). The unmyelinated fibers showed the largest diameter (62\%) varying from 0.25 to $0.75 \mu \mathrm{m}$ as seen in the Fig. 15. The mean value was $0.6 \mu \mathrm{m}$ being that the maximum value was $3.17 \mu \mathrm{m}$ and the minimum was $0.2 \mu \mathrm{m}$. The smallest diameter was obtained in $44 \%$ of unmyelinated fibers which the diameter ranges from 0.2 to $0.4 \mu \mathrm{m}$. Then, the minimum value obtained was $1 \mu \mathrm{m}$ and the minimum was $0.12 \mu \mathrm{m}$ (Fig.16). 

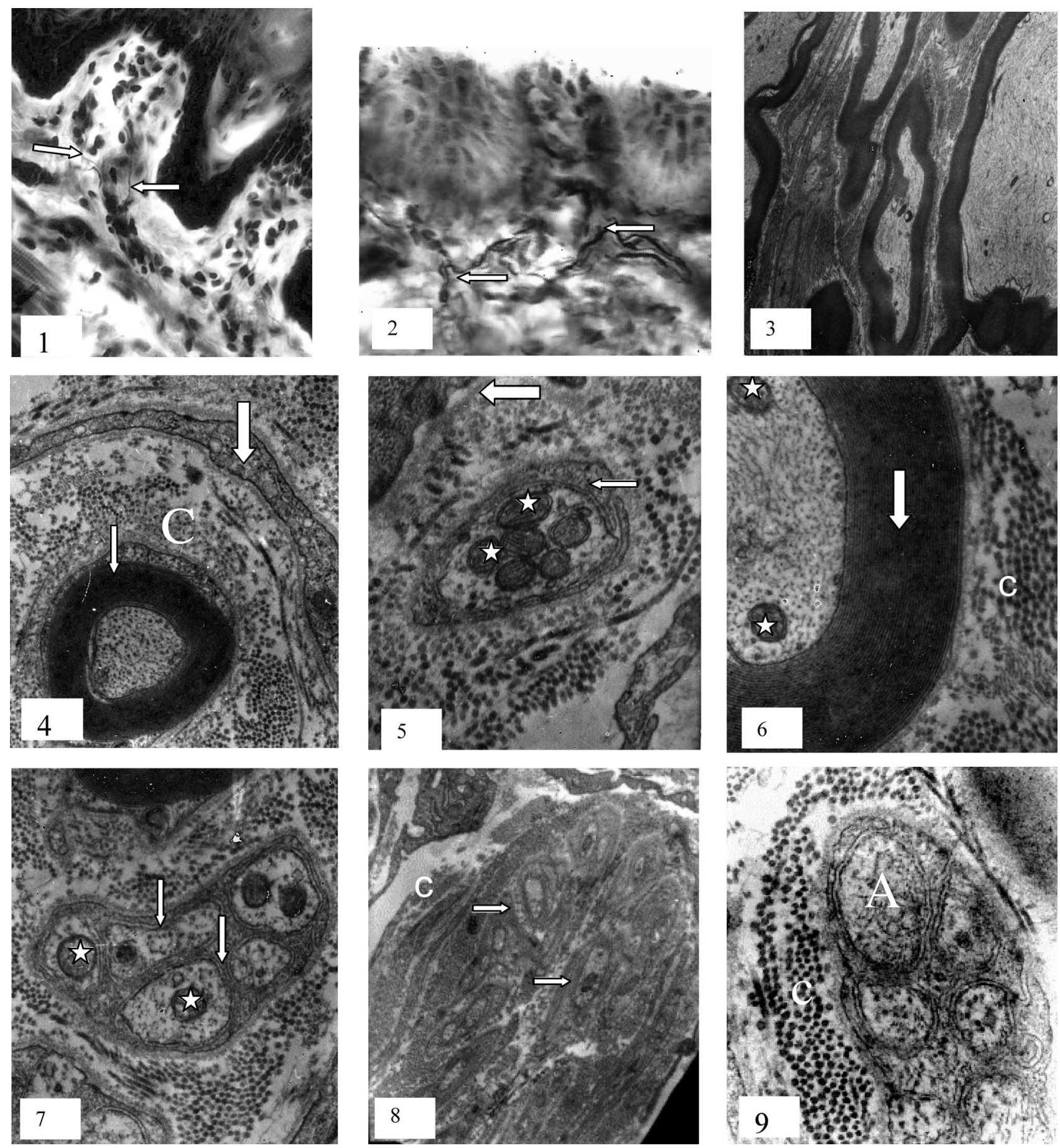

Fig. 1 Silver impregnation method. The tongue mucosa of aging rat present stratified epithelium and the lamina propria containing the nerve fibers with an irregular traject (arrows). X 250.

Fig. 2 The bundles of nerve fibers arise from deep portion of tongue revealing into the subepithelial connective tissue (arrows). X 250 .

Fig. 3 The bundles of myelinated nerve fibers were surrounded by collagen fibers. X 10,000.

Fig. 4 Into the lamina propria of tongue mucosa revealed the thin myelinated nerve fiber (small arrow) enveloped by perineural cell cytoplasmic lamina (large arrow). The collagen fibers are seen (C). X 46,500.

Fig. 5 The unmyelinated nerve terminal is enveloped by a thin lamina of Schwann cell sheets (small arrow). Numerous mitochondria (*) and basement mebrane (large arrow) are shown. X 36,000.

Fig. 6 The axoplasm of myelinated nerve fiber contains the mitochondria (*) and neurofilaments. The myelin sheet of myelinated nerve fiber (large arrow) and the fine collagen fibers (C) are noted. X 65,400.

Fig. 7 The bundles of unmyelinated nerve fibers were surrounded by thin sheets of Schwann cells (small arrows). The axons present neurofilaments, microtubules and mitochondria (*). X 55,000.

Fig. 8 The grouping of unmyelinated fibers are enveloped by Schwann cell laminae (arrows) and at periphery may observe the bundles of collagen fibers (c). X 21,000.

Fig. 9 Shows the unmyelinated nerve fibers (A) and at periphery, the bundles of collagen fibers (C). X 69,000. 

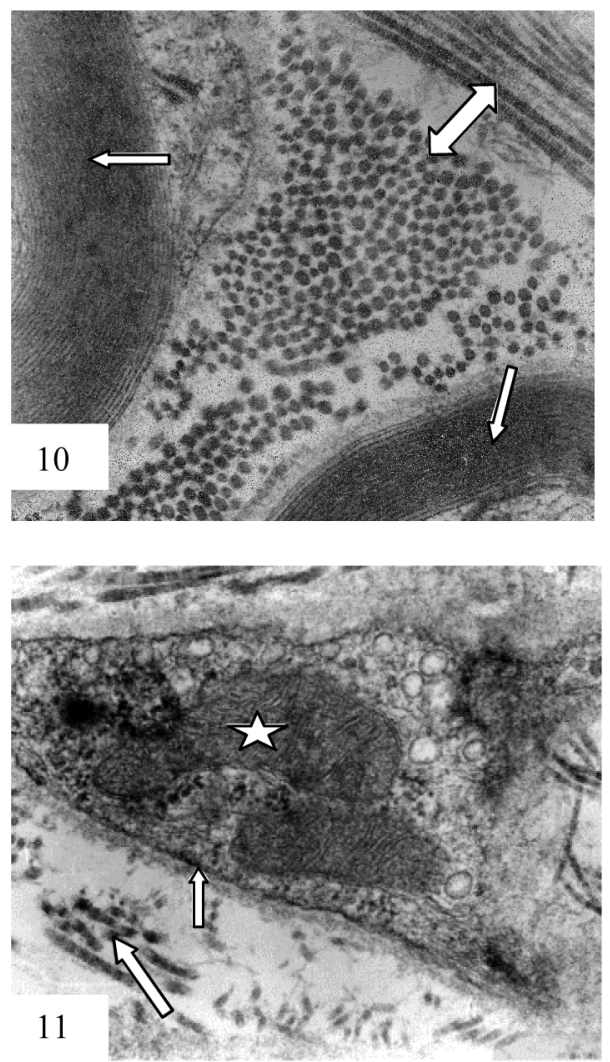

Fig. 10 Between the myelinated nerve fibers (small arrows), the endoneurium containing the transversal and longitudfinal collagen fibers (large arrows). X 69,000.

Fig. 11 The cytoplasm of Schwann cell present the mitochondria $\left.{ }^{*}\right)$ and basement membrane (small arrow) collagen fibers (large arrows). X 70,500.

Fig. 12 Shows the distribution of maximum diameter (in micrometer) of myelinated nerve fibers.

Fig. 13 Shows the variation of minimum diameter (in micrometer) of myelinated nerve fibers.

Fig. 14 Shows the variation of thickness of myelin sheets.

Fig. 15 Shows the distribution of maximum diameter (in micrometer) of unmyelinated nerve fibers.

Fig. 16 Shows the variation of minimum diameter (in micrometer) of unmyelinated nerve fibers.
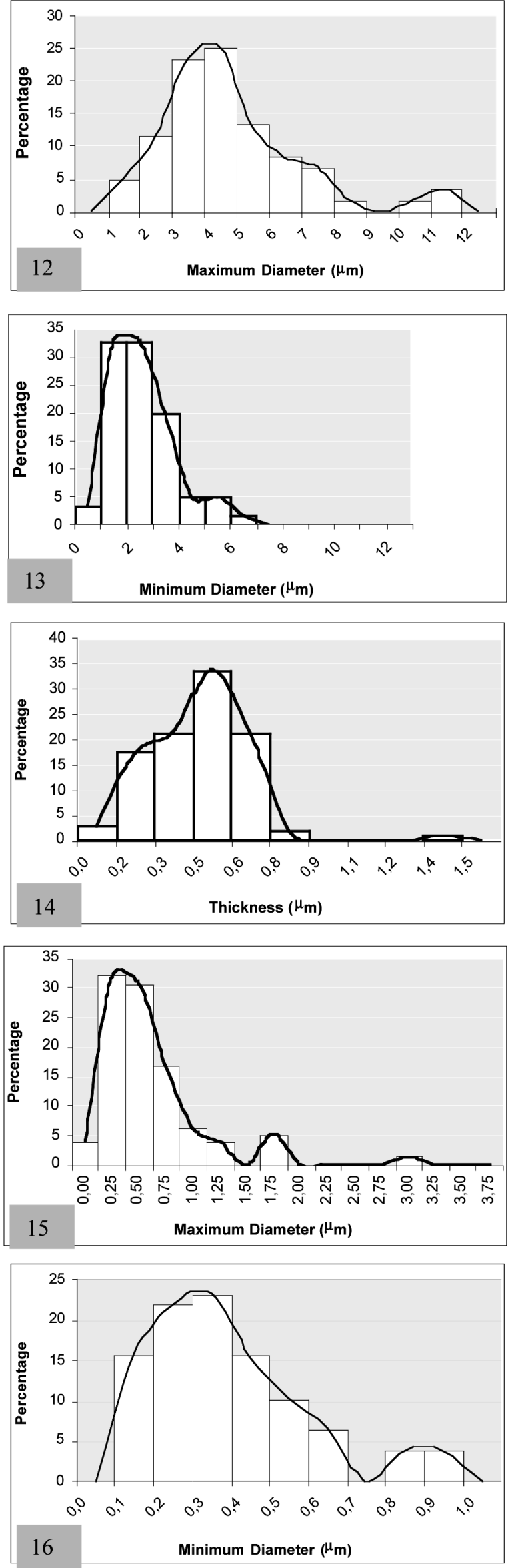


\section{DISCUSSION}

Our data demonstrated the myelinated and unmyelinated nerve fibers of aging rat tongue mucosa. As observe in our results, the complex network of nerve fibers was found in the lamina propria revealing single terminal axons and ramified nerve endings, clearly revealed by silver inmpregnation method. Ceccherelli (1908), Nakayama (1943a, 1943b) Ohgaki (1953), Nakai (1960) and Watanabe \& Konig (1977) identified the myelinated, unmyelinated nerve fibers and sensory nerve endings in human and monkey tongue papillae. In our results may demonstrate the terminal nerve endings presenting single and organized nervous structures also, forming the mechanoreceptors. Ormea and Re (1952) and Semprini \& Watanabe (1983) reported the sensory nerve terminals in oral mucous of cats and guinea pigs. On the other hand, the organized nerve terminals were found into the connective tissue of papillae as reported by Gairns (1955). Our observations confirmed those reported by Seto (1963) emphazing that large papilla like fungiform and vallate present numerous well developed bundles of nerve fibers with their terminal axons.

Although, our data revealed that ultrastructurally, the bundles of subepithelial nerve fibers in aging rats contain myelinated and unmyelianated nerve fibers surrounded by thin lamina of perineural cells. Also, confirmed that the cytoplasmic lamina of perineural cells present the mitochondria, rough endoplasmic reticulum and small vesicles.

Our data showed that the filiform papillae presented few terminal axons revealing single form in comparison with other lingual papillae. Okano (1953) found few sensory nerve endings in the filiform papillae of the dog tongue, and these nerve endings presented single subepithelial terminals axons and intraepithelial nerve endings. On the other hand, the nerve fiber found in the filiform papillae of rat tongue usually are thin terminal axons, which are agree to those reported by Böck (1971). The bundles of nerve fibers showed the unmyelinated and myelinated nerve fibers in the filiform papillae.

Kubota et al. (1966) demonstrated that in the fungiform papillae of the porcupine tongue, did not show the taste buds; however, these papillae are supplied with numerous thin nerve fibers. The papillae found in the ventral surface of apex of tongue and, the ventral face of the porcupine tongue may present sensory afferent fibers. In the vallate papilla was noted the presence of thick bundles of nerve fibers ascending into the connective tissue with branched in terminals fibers of subepithelial plexus. It was verified that from this plexus the thin nerve fibers run to the epithelial layer of lateral wall of vallate in order to innervated the taste buds. Okano had reported that in the vallate papillae of dog tongue and by Watanabe \& Konig (1977) in the vallate papillae of Cebus apella monkey.

In our results was noted that thin nerve fibers reaching to the lateral part of vallate papilla, where there are more concentration of the taste buds. Kubota \& Hayama (1964) and Kubota \& Togawa noted that in the lateral wall of the vallate papilla of the wild rats, the taste buds present abundant innervation similar to those observed in our data. Also, it was demonstrated that in the aging rats the nerve fibers may present the variation in the diameter and the thickness of myelin sheets. The histogram elucidate these variations of myelinated and unmyelinated nerve fibers with aging. Our results will be important to analyse the nerve fibers in different conditions in the future experimental groups comparing in differents ages.

GRISOLIA, D. F.; OGAWA, K.; MOTOYAMA, A. A.; KRONKA, M. C.; CARNEIRO JR., J. T.; DURO, C. C. \& WATANABE, I. Ultraestructura de las fibras mielínicas y amielínicas de la mucosa lingual de ratas albinas (Wistar) envejecidas. Int. J. Morphol., 24(3):407412, 2006.

RESUMEN: El objetivo de esta investigación fue estudiar las fibras sensitivas mielinizadas y amielínicas localizadas en la lámina propia subepitelial de la mucosa lingual de ratas. Se usó el método de impregnación argéntica, microscopía MET y mediciones morfométricas. Los resultados revelaron que los fascículos de fibras subepiteliales de las regiones anterior, media y posterior de la lengua provenían de su capa muscular profunda. Los grupos de fibras fueron localizados dentro del tejido conectivo de la lámina propia. Estas fibras nerviosas se ramificaron varias veces y en el tejido conectivo de las papilas formaron terminaciones simples o ramificados. Las papilas fungiformes y valadas contenían numerosas terminaciones nerviosas. La ultraestructura demostró en el axoplasma la presencia de neurofilamentos, mitocondrias y microtúbulos; aunque los registros morfométricos de las fibras mielinizadas mostraron que alrededor del $44 \%$ tenían un diámetro entre 3 y 4 $\mu \mathrm{m}$, el valor promedio fue de $4.5 \mu \mathrm{m}$. El diámetro mayor fue de $12 \mu \mathrm{m}$ y el menor de $1.4 \mathrm{um}$. Los rangos de menores diámetros fueron de 1 a $3 \mu \mathrm{m}$, siendo el promedio de $2.33 \mu \mathrm{m}$. En relación al espesor de las vainas de mielina, los valores obtenidos fueron de 0.2 a 0.8 um siendo el valor promedio de alrededor de $0,5 \mu \mathrm{m}$, en el $90 \%$ de ellas. En las fibras amielínicas los mayores diámetros $(62 \%)$ variaron entre 0.25 y 0.75 $\mu \mathrm{m}$. El valor promedio fue de $0.6 \mu \mathrm{m}$, siendo el valor máximo $3.17 \mu \mathrm{m}$ y el mínimo $0.2 \mu \mathrm{m}$. El menor diámetro fue obtenido en $44 \%$ de las fibras amielínicas y los rangos variaron entre 0.2 y $0.4 \mu \mathrm{m}$. El valor máximo obtenido fue de $1 \mu \mathrm{m}$ y el mínimo $0.12 \mu \mathrm{m}$.

PALABRAS CLAVE: Fibra nerviosa; Fibra mielinizada; Fibra amielínica; Mucosa lingual; Ratas envejecidas; TEM. 


\section{REFERENCES}

Böck, P. The nerve of the filiform papillae of the guinea pig. Excepta Med., 25:632, 1971.

Ceccherelli, G. Sulle espansioni nervose di senso nella mucosa della lingua dell’uomo. Anat. Anz., 25:56-69, 1908.

Eto, S. On the sensory nerve distribuition in the mucous membrane of the cavum oris and the pars nasalis pharyngis of cat in the last fetal stage. Arch. Histol. Jap., 17:569-89, 1959.

Fonoff, R. N.; Watanabe, I.; Kao, T. H.; Iyomasa, M. M. Morfologia das terminações nervosas sensitivas da porção anterior da mucosa lingual de macaco Cebus apella. An. Anat. Norm., 5:218-20, 1987.

Fonoff, R. N.; Watanabe, I. \& Kao, T. H. Sensory nerve endings of the medium and posterior parts of Cebus apella monkey's tongue mucosa. Rev. Odont. USP, 3:377-82, 1989.

Gairns, F. W. The sensory nerve endings in the human palate. Quart. J. Exp. Physiol., 40: 40-8, 1955.

Kubota, K.; Kubota, J.; Fukuda, N.; Asakura, S.; Nakagawa, S. $\&$ Masui, M. Comparative anatomical and neurohistological observations on the tongue of marsupials. Anat. Rec., 147:337-53, 1963.

Kubota, K. \& Hayama, S. Comparative anatomical and neurohistological observations on the tongues of pigmy and common marmosets. Anat. Rec., 150:473-86, 1964.

Kubota, K. \& Togawa, S. Comparative anatomical and neurohistological observations on the japanese dormouse (Glirus japonicus). Anat. Rec., 154:545-52, 1966.

Kubota, K.; Fukuda, N. \& Asakura, S. Comparative anatomical and neurohistological observations on the tongue of the Porcupine (Histrix cristata). Anat. Rec., 155: 261-8, 1966.

Nakai, R. Supplement of the histological observations on the sensory nerve supply of the human tongue. Arch. Histol. Jpn., 20:161-78, 1960.

Nakayama, T. On intraepithelial nerve fibers in human tongue. Tohokun Igaku Zassi, 33:447-56, 1943a.

Nakayama, T. Histological studies on nerves in human tongue papilla especially on sensory nerve endings. Tohokun Igaku Zassi, 33:473-85, 1943b

Ohgaki, M. Innervation especially sensory innervation of facies inferior linguae in human adult. Tohoku J. Exp. Med., 59:371, 1953.
Okano, S. Innervation specially sensory innervation of dog tongue. Tohoku J. Exp. Med., 57:169-79, 1953.

Ormea, F. \& Re, G. Structure nervose e funzione nervose della regione buccale. Minerva Dermat., 35:39-55, 1952.

Reynolds, E. S. The use of lead citrate at high $\mathrm{pH}$ as an electronopaque stain in electron microscopy. J. Cell. Biol., 17:208, 1963.

Sato, M. \& Sato, T. Fine estructure of developed human tongue muscle. Okajimas Folia Anat. Jpn., 69:115-30, 1992.

Semprini, M. \& Watanabe, I. Observações neurohistológicas da mucosa da bochecha de cobaias. RGO, 31:197-9, 1983.

Seto, H. Studies of sensory innervation. 2 ed. Springfiled, Thomas, 1963 Chap. 8: 104-217.

Watanabe, I. \& Semprini, M. Light and electron microscopy observations in the rat gingiva nerve endings. A silver impregnation and a transmission electron microscopy study. Rev. bras. Cienc. morfol., 2:10- 8, 1985.

Watanabe, I. \& Konig Jr, B. Innervation of the palatine mucous membrane in the Cebus apella monkey. Tohoku J. Exp. Med., 123:215-20,1977.

Watanabe, I. \& Yamada, E. The fine structure of lamellated nerve endings found in the rat gingiva. Arch. Histol. Jpn., 46:17382, 1983.

Watson, M. L. Staining of tissue sections for electron microscopy with heavy metals. J. Biophys. Biochem. Cytol., 4:475-8, 1958.

Winkelman, R. K.; Schmit, R. W. A simple silver method for nerve axoplasm. Proc. Staff. Meet. Mayo Clin., 32:217-22, 1957.

Correspondence to:

Prof. Dr. Ii-sei Watanabe

Department of Anatomy

Institute of Biomedical Sciences

Universidade de São Paulo

Av. Prof. Lineu Prestes, 2415 - Cidade Universitária

CEP 05508-900 - São Paulo - SP

BRASIL

Email:watanabe@ic6.usp.br

Received: 29-03-2006

Accepted: 14-06-2006 